\title{
SULFAPYRIDINE IN EXPERIMENTAL PNEUMOCOCCIC PNEUMONIA IN THE DOG ${ }^{1}$
}

\author{
By LUCIEN A. GREGG, MORTON HAMBURGER, AND CLAYTON G. LOOSLI
}

(From the Department of Medicine and the Douglas Smith Foundation for Medical Research of the University of Chicago, Chicago)

(Received for publication September 21, 1939)

Previously reported studies of the action of sulfapyridine in experimental pneumococcic infection have been carried out in the mouse, rabbit, and rat-species which, unlike man, are highly susceptible to the pneumococcus.

Whitby (1) found that mice infected with Type I pneumococci and treated with sulfapyridine possessed after recovery considerable immunity to the same organism. A similar observation was made by Schmidt and Hilles (2). Whether acquired immunity plays an essential rôle in the mechanism of recovery in treated mice is not known, but there is some indirect evidence to suggest that it may do so. Especially significant is MacLeod's (3) observation on mice infected with pneumococci Types I, II and III, respectively, that the survival rate for each type was closely similar in actively immunized and in sulfapyridinetreated groups. Furthermore, there is clearly demonstrable a synergistic antipneumococcic action in vivo between artificially induced immunity and sulfapyridine, as shown by the work of Powell and Jamieson (4), MacLean, Rogers, and Fleming $(5,6)$, and Kepl and Gunn (7). From these considerations it would seem that natural antipneumococcic resistance of a relatively high order, such as that possessed by human beings as a group (8), may enhance the effectiveness of sulfapyridine.

The dog resembles man in ability to localize pneumococci in the tissues and in degree of natural humoral immunity. O. H. Robertson and coworkers $(9,10)$, have shown that lobar pneumonia, which in all essential respects is comparable to the human disease, can be produced in the dog. They have demonstrated further that mortality in the experimental disease can be regulated, within certain limits, by varying the infect-

\footnotetext{
1 Preliminary report appeared in the Proceedings of the Society for Experimental Biology and Medicine, 1939, 41, 459-462.
}

ing dosage of pneumococci, that there is a direct relationship between extent of pulmonary involvement and death rate, and that there is a steadily rising mortality with increasing degrees of leukopenia and of bacteremia which is of definite prognostic significance even at 24 hours (11).

The present report concerns observations on the course of pneumococcus Type I pneumonia in 34 dogs treated with sulfapyridine, ${ }^{2}$ the administration of which was begun before infection and at various stages of the disease. An infecting dose of culture was selected which would result in a disease severe enough to provide a crucial test for the drug but not so fulminating that spontaneous recovery would be impossible. Simultaneous untreated controls were employed throughout the study.

Canine pneumonia differs from the human disease in having a more rapid course. This feature is to be borne in mind when considering the time at which treatment was begun in this investigation.

\section{METHODS AND MATERIALS}

Dogs weighing 8 to 15 kilograms were infected intrabronchially by the method of Robertson and Fox (11) with $1 \mathrm{cc}$. of a 16-hour pneumococcus culture followed by $3 \mathrm{cc}$. of animal mucin. The microorganisms were separated from the culture medium and resuspended in 1 cc. of Locke's solution containing 0.1 per cent gelatin. In the special instances where $0.02 \mathrm{cc}$. of culture was used, it was mixed directly with $1 \mathrm{cc}$. of a 6 per cent starch-broth medium, no mucin being employed. The same strain of Type I pneumococcus $\left(A_{5}\right)$ was used throughout. It had been passed through a rabbit every 6 weeks, and through a dog on 2 occasions, to maintain its virulence.

Sulfapyridine was administered orally in capsules or compressed tablets.

The concentration of sulfapyridine in the blood and exudates was determined by the method of Marshall and

\footnotetext{
2 The sulfapyridine used in this investigation was kindly furnished by Merck and Co.
} 
Litchfield $^{8}$ (12). The pneumococcidal-promoting power of serum was tested in serum-leukocyte mixtures by the method of Robertson and Sia (13). When color change appeared, indicating growth, the tubes were opened and their contents examined for organisms in stained films. All tubes showing no color change were examined in the same way at 72 hours. The test is so assembled that $0.3 \mathrm{cc}$. of serum is diluted with the other constituents to a final volume of $0.5 \mathrm{cc}$. Blood cultures were made in the usual manner, using $1 \mathrm{cc}$. of blood to $10 \mathrm{cc}$. of melted agar. In addition, after treatment had been instituted, cultures were also made with $1 \mathrm{cc}$. of blood in $25 \mathrm{cc}$. of broth to achieve even greater dilution of drug present in the blood.

Roentgenograms of the chest (14) were made at the time treatment was begun and almost daily thereafter until recovery or death occurred. Body temperatures were taken rectally, at least twice a day, morning and late afternoon. Pulmonary exudate for bacteriologic examination was obtained postmortem by piercing the seared surface of the lung with a sterile capillary pipette.

\section{EXPERIMENTAL}

\section{Outcome and duration of the disease. Effect of treatment when begun within 24 hours of infection}

In the 32 dogs employed as controls during this study, the mortality was 50 per cent, and the disease was brief in duration whatever the outcome (Table I). Within 72 hours of the time of infection the temperature had fallen to normal in all but 2 of the 16 animals that ultimately survived. Of the 16 that died, only 3 lived for more than 96 hours.

Twenty-four dogs were given sulfapyridine on the first day of the disease, beginning 3 to 24 hours after infection, and 3 times daily thereafter for 2 to 5 days (Table I). The total quantity of drug that each received was 0.25 to 0.8 gram per kilo of body weight, an average of $0.5 \mathrm{gram}$ per kilo. In 9 instances where serial blood determinations were made, the content of free sulfapyridine was generally 2 to $8 \mathrm{mgm}$. per cent during the first 2 days of administration, having reached that level within 6 hours (Table III).

Of the 24 dogs so treated, none died. Eleven were used in other experiments 10 to 60 days after recovery, when $x$-ray examination showed

8 The figures in our data represent only the free sulfapyridine concentrations in the blood and empyemic fluid.
TABLE I

Mortality and duration of fever in controls and in dogs treated with sulfapyridine

Treatment begun within 24 hours after infection

\begin{tabular}{|c|c|c|c|c|c|c|c|c|}
\hline \multicolumn{2}{|c|}{ Sulfapyridine } & \multirow[b]{2}{*}{ 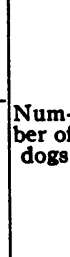 } & \multicolumn{5}{|c|}{$\begin{array}{l}\text { Duration of fever * } \\
\text { Number of dogs showing drop } \\
\text { of temperature to normal }\end{array}$} & \multirow[b]{2}{*}{$\begin{array}{l}\text { Total } \\
\text { mor- } \\
\text { tality }\end{array}$} \\
\hline $\begin{array}{l}\text { Begun at } \\
\text { intervals } \\
\text { after } \\
\text { infection }\end{array}$ & $\begin{array}{l}\text { Total } \\
\text { amount } \\
\text { given }\end{array}$ & & $\begin{array}{l}\text { with- } \\
\text { in } \\
24 \\
\text { hours }\end{array}$ & $\begin{array}{c}\text { be- } \\
\text { tween } \\
24 \\
\text { and } \\
48 \\
\text { hours }\end{array}$ & $\begin{array}{c}\text { be- } \\
\text { tween } \\
48 \\
\text { and } \\
72 \\
\text { hours }\end{array}$ & $\begin{array}{c}\text { be- } \\
\text { tween } \\
72 \\
\text { and } \\
96 \\
\text { hours }\end{array}$ & $\begin{array}{c}\text { af- } \\
\text { ter } \\
96 \\
\text { hours }\end{array}$ & \\
\hline hours & grams & & & & & & & $\begin{array}{c}\text { per } \\
\text { cent }\end{array}$ \\
\hline $\begin{array}{c}3 \\
12 \\
18 \text { to } 24\end{array}$ & $\begin{array}{l}5 \text { to } 7 \\
5 \text { to } 6 \\
3.7 \text { to } 6\end{array}$ & $\begin{array}{r}10 \\
5 \\
9\end{array}$ & $\begin{array}{l}0 \\
0 \\
1\end{array}$ & $\begin{array}{l}\mathbf{5} \\
\mathbf{3} \\
\mathbf{2}\end{array}$ & $\begin{array}{l}3 \\
2 \\
5\end{array}$ & 1 & 1 & 0 \\
\hline \multicolumn{2}{|c|}{$\begin{array}{c}\text { Control dogs } \\
\text { Surviving... } \\
\text { Dying } \dagger . . .\end{array}$} & $\begin{array}{l}16 \\
16\end{array}$ & $\begin{array}{l}1 \\
1\end{array}$ & $\begin{array}{l}4 \\
4\end{array}$ & $\begin{array}{l}9 \\
4\end{array}$ & $\begin{array}{l}1 \\
4\end{array}$ & $\begin{array}{l}1 \\
3\end{array}$ & 50 \\
\hline
\end{tabular}

Dosage of drug: initial dose 2 or 3 grams, followed in 6 to 8 hours with $1 / 3$ gram three times a day for 2 to 5 days. * Temperatures (rectal) above $102.9^{\circ} \mathrm{F}$. considered to indicate fever.

$\dagger$ Figures in columns 4 to 8 indicate time of death.

beginning or complete resolution of the pneumonia. The others were sacrificed for pathological study 6 to 40 days after infection, or killed because they had developed "snuffles" several days or weeks after having recovered from the experimental pneumococcal disease. Cultures taken postmortem from lesions not yet resolved yielded no pneumococci. The lungs of 3 dogs with "snuffles" contained gram-positive cocci and gram-negative bacilli."

The duration of fever (Table I) in animals receiving the first dose of sulfapyridine on the 18th or 24th hour of the disease was practically the same as it was in the controls that survived. When treatment was begun as early as the 12th hour, more than one-half of the dogs showed a normal temperature by the 48th hour, whereas less than one-third of the surviving controls did so.

Nearly all of the treated dogs continued to have fever for at least 24 hours after the beginning of treatment.

4 In this laboratory these organisms have often been found in the lungs of dogs with acute epidemic respiratory disease commonly called "snuffles." 
Relation to outcome of extent of pulmonary involvement, white blood count, and occurrence of bacteremia at the 24th hour of the disease

In the control dogs (Table II) the close correlation between extent of lung involvement and outcome is evident. When the pulmonary lesion at 24 hours involved not more than one-sixth of the total lung field, as judged from an $x$-ray film (approximately one lobe), all but one of 9 dogs recovered; when it occupied one-half or more of the total lung field, 9 of 13 died. The presence

\section{TABLE II}

Extent of pulmonary involvement, white blood count and incidence of bacteremia 24 hours after infection in controls and in dogs treated with sulfapyridine. Relationship to outcome.

Treatment begun within 24 hours after infection

\begin{tabular}{|c|c|c|c|c|c|c|c|c|c|c|}
\hline \multirow{3}{*}{$\begin{array}{l}\text { Treat- } \\
\text { ment } \\
\text { begun } \\
\text { at } \\
\text { intervals } \\
\text { after } \\
\text { infection }\end{array}$} & \multirow{3}{*}{$\begin{array}{c}\text { Total } \\
\text { number } \\
\text { of } \\
\text { dogs }\end{array}$} & \multirow{2}{*}{\multicolumn{3}{|c|}{$\begin{array}{c}\begin{array}{c}\text { Extent of pulmo- } \\
\text { nary lesion ( } x \text {-ray) }\end{array} \\
\begin{array}{c}\text { Number of dogs with } \\
\text { involvement of }\end{array}\end{array}$}} & \multirow{2}{*}{\multicolumn{2}{|c|}{$\begin{array}{c}\begin{array}{c}\text { White blood } \\
\text { count }\end{array} \\
\begin{array}{c}\text { Number of } \\
\text { dogs with } \\
\text { white blood } \\
\text { count of }\end{array}\end{array}$}} & \multirow{2}{*}{\multicolumn{4}{|c|}{$\begin{array}{c}\text { Incidence of bacteremia } \\
\begin{array}{c}\text { Number of dogs with } \\
\text { colony count per } \\
\text { cc. of blood }\end{array}\end{array}$}} \\
\hline & & & & & & & & & & \\
\hline & & $\begin{array}{l}1 / 6 \text { or } \\
\text { less } \\
\text { of } \\
\text { total } \\
\text { lung } \\
\text { feld }\end{array}$ & $\begin{array}{l}1 / 3 \pm \\
\text { of } \\
\text { total } \\
\text { lung } \\
\text { fiold }\end{array}$ & $\begin{array}{l}1 / 2 \text { or } \\
\text { more } \\
\text { of } \\
\text { total } \\
\text { lung } \\
\text { field }\end{array}$ & $\begin{array}{c}2,000 \\
\text { and } \\
\text { above }\end{array}$ & $\begin{array}{c}1,900 \\
\text { and } \\
\text { below }\end{array}$ & 0 & $\begin{array}{l}1 \\
\text { to } \\
20\end{array}$ & $\begin{array}{c}21 \\
\text { to } \\
100\end{array}$ & $\begin{array}{c}101 \\
\text { or } \\
\text { more }\end{array}$ \\
\hline $\begin{array}{c}\text { hours } \\
3 \\
12 \\
18-24\end{array}$ & $\begin{array}{r}10 \\
5 \\
9\end{array}$ & $\begin{array}{l}1 \\
4 \\
2\end{array}$ & $\begin{array}{l}6 \\
1 \\
4\end{array}$ & $\begin{array}{l}\mathbf{3} \\
\mathbf{0} \\
\mathbf{3}\end{array}$ & $\begin{array}{l}7 \\
3 \\
6\end{array}$ & $\begin{array}{l}3 \\
2 \dagger \\
3\end{array}$ & $\begin{array}{l}8 \\
5 \\
6\end{array}$ & $\begin{array}{l}2 \\
0 \ddagger \\
1\end{array}$ & $\begin{array}{l}0 \\
0 \\
1\end{array}$ & $\begin{array}{l}0 \\
0 \\
1\end{array}$ \\
\hline Controls & $31(15)^{*}$ & $\theta(1)$ & $9(5)$ & $13(9)$ & $22(9)$ & $9(6)$ & $20(7)$ & $6(3)$ & $1(1)$ & $4(4)$ \\
\hline
\end{tabular}

Figures in parentheses indicate number of dogs dying. * One dog died in less than 24 hours.

$\dagger$ Present at 12 hours.

$\ddagger$ Positive in 2 at 12 hours.

of bacteremia 24 hours after infection was associated with a fatal outcome in 8 of the 11 control dogs in which it occurred. None survived whose blood at 24 hours contained on culture more than 20 colonies per cc. The relationship between white blood count and outcome is less obvious in this small series than in the much larger one reported by Robertson and Fox (11).

In the group receiving the first dose of sulfapyridine 18 or 24 hours after inoculation (Table II) there was an expected incidence of widespread lung involvement, blood stream invasion, and profound leukopenia; yet all recovered.
Effect of early treatment on extent of pulmonary lesion, and on incidence of leukopenia and bacteremia at the 24th hour of the disease

The pulmonary lesion at 24 hours (Table II) involved one-half or more of the total lung field in nearly one-half of the control dogs. Such an extensive pneumonia occurred in only one-fifth of those treated within 12 hours of inoculation. However, there was involvement of at least onethird of the lung field at the 24th hour in 9 out of the 10 dogs treated as early as the 3rd hour.

Extension of the pneumonic process after 24 hours was seen by $x$-ray in only one of the controls that survived. Of those that died, one-half showed a gross spread, as determined from a comparison of the size of the x-ray shadow occurring at the 24th hour and the extent of consolidation found at autopsy.

Among the treated dogs, spread occurred after the 24th hour of the disease in only 2 of the 15 treated within 12 hours; in one instance between the 24th and 48th hour and in the other between the 48th and 72 nd hour as well. It occurred in 5 of the 9 dogs not treated until the 18th or 24th hour, but in only one of these did it continue beyond the 48th hour.

Bacteremia at 24 hours (Table II) was found in more than one-third of the control dogs, but in only 2 of the 15 treated within 12 hours of infection, and in the latter it was minimal and disappeared by the 48th hour. Early treatment did not appreciably reduce the incidence of extreme leukopenia (Table II).

\section{Effect of treatment on antipneumococcic activity of the blood}

The sera of 11 of the 24 recovered dogs in the treated series were tested for mouse-protective action 3 to 22 days after recovery, and this property was found in the sera of 8 of the animals.

Serum was collected before infection and during the course of treatment from dogs receiving the first dose of sulfapyridine 18 or 24 hours after infection and examined for pneumococcidalpromoting power in serum-leukocyte mixtures by the method of Robertson and Sia. The results of these tests revealed in general a slight enhancement of this property within 24 hours after the 
TABLE III

Course of bacteremia, pneumococcidal-promoting power of the serum, and concentration of sulfapyridine in the blood

Dogs that received the first dose of sulfapyridine 18 or 24 hours after infection

\begin{tabular}{|c|c|c|c|c|}
\hline $\begin{array}{c}\text { Dog } \\
\text { number }\end{array}$ & Time of observations & $\begin{array}{c}\text { Blood } \\
\text { culture }\end{array}$ & $\begin{array}{l}\text { Pneumo- } \\
\text { coccidal- } \\
\text { promoting } \\
\text { power } \\
\text { of serum }\end{array}$ & $\begin{array}{l}\text { Concen- } \\
\text { tration } \\
\text { of } \\
\text { sulfapy- } \\
\text { ridine } \\
\text { in the } \\
\text { blood }\end{array}$ \\
\hline $220 \mathrm{~T}$ & 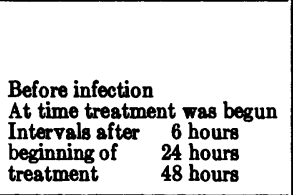 & $\begin{array}{c}\begin{array}{c}\text { colonies } \\
\text { pneumococci } \\
\text { per cc. blood }\end{array} \\
0 \\
0 \\
0 \\
-\end{array}$ & $\begin{array}{c}\text { number of } \\
\text { pneumococei } \\
\text { killed } \\
10^{6}, 10^{5} \\
10^{5} \\
10^{6} \\
10^{6} \\
-\end{array}$ & $\begin{array}{c}\text { mom. } \\
\text { per } \\
\text { cent }\end{array}$ \\
\hline $225 \mathrm{~T}$ & $\begin{array}{l}\text { Before infection } \\
\text { At time treatment was begun } \\
\text { Intervals after } 6 \text { hours } \\
\text { beginning of } \quad 24 \text { hours } \\
\text { treatment } \\
\end{array}$ & $\begin{array}{l}0 \\
0 \\
0 \\
0\end{array}$ & $\begin{array}{l}10^{5} \\
10^{6} \\
10^{6} \\
\frac{10^{5}}{}\end{array}$ & $\begin{array}{l}3.4 \\
6.4 \\
4.5\end{array}$ \\
\hline $238 \mathrm{~T}$ & $\begin{array}{l}\text { Before infection } \\
\text { At time treatment was begun } \\
\text { Intervals after } \quad 6 \text { hours } \\
\text { begining of } \quad 24 \text { hours } \\
\text { treatment } \\
\end{array}$ & $\begin{array}{l}0 \\
0 \\
0 \\
-\end{array}$ & $\frac{10^{4}}{10^{5}}$ & $\begin{array}{l}4.2 \\
6.4 \\
1.4\end{array}$ \\
\hline $241 \mathrm{~T}$ & 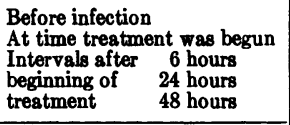 & $\begin{array}{l}0 \\
0 \\
0 \\
\end{array}$ & $\bar{z}$ & $\begin{array}{l}6.0 \\
1.6 \\
1.4\end{array}$ \\
\hline $232 \mathrm{~T}$ & 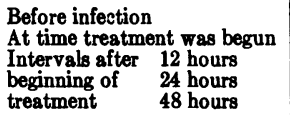 & $\begin{array}{l}0 \\
0 \\
0 \\
0\end{array}$ & $\frac{10^{6}, 10^{5}}{10^{6}}$ & $\begin{array}{l}6.0 \\
5.2 \\
1.6\end{array}$ \\
\hline $249 \mathrm{~T}$ & $\begin{array}{l}\text { Before infection } \\
\text { At time treatment was begun } \\
\text { Intervals after } 24 \text { hours } \\
\text { begining of } \quad 48 \text { hours } \\
\text { treatment }\end{array}$ & $\begin{array}{l}0 \\
0 \\
0\end{array}$ & $\begin{array}{l}10^{6} \\
10^{4} \\
10^{6} \\
-\end{array}$ & $\begin{array}{l}3.1 \\
3.6\end{array}$ \\
\hline $219 \mathrm{~T}$ & 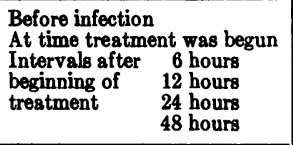 & $\begin{array}{c}230 \\
39 \\
10 \\
\text { pos.* } \\
0 \dagger\end{array}$ & $\begin{array}{l}10^{4}, 10^{5} \\
10^{4} \\
\frac{10^{6}}{-}\end{array}$ & $\begin{array}{l}1.6 \\
5.6 \\
4.8 \\
3.6\end{array}$ \\
\hline $222 \mathrm{~T}$ & 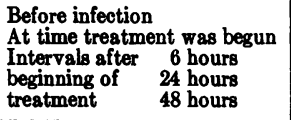 & $\begin{array}{l}1 \\
0 \\
0 \\
0\end{array}$ & $\begin{array}{c}10^{5}, 10^{6} \\
10^{4} \\
10^{6} \\
=\end{array}$ & $\begin{array}{c}5.0 \\
4.6 \\
\text { trace }\end{array}$ \\
\hline $229 \mathrm{~T}$ & 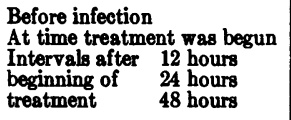 & $\begin{array}{c}26 \\
\text { pos.* } \\
0 \\
0\end{array}$ & $\begin{array}{l}10^{4}, 10^{4} \\
10^{4} \\
10^{5} \\
10^{5} \\
-\end{array}$ & $\begin{array}{r}11.0 \\
8.4 \\
1.1\end{array}$ \\
\hline
\end{tabular}

* = Growth in broth culture only.

$\dagger=$ Blood cultures made at 72nd and 96th hour also negative.

$-=$ Not done.

initiation of treatment (Table III). When the samples possessing this increased activity were tested in the same way, but with hemoglobin solution substituted for the leukocyte suspension, there was growth of even the smallest inoculum of pneumococci (approximately 10 organisms).

\section{Effect of treatment on the course of bacteremia}

Three of the dogs receiving the first dose of sulfapyridine 18 or 24 hours after infection were bacteremic at the time treatment was begun ( $\mathrm{Ta}$ ble III). The colony counts were respectively 1 , 26 and 230 per cc. of blood. Blood cultures made 24 hours later were negative in poured agar plates, but in one instance still positive in the broth. In only 1 of the 3 animals had there been a measurable decrease in the titer of circulating antibody by the time treatment was started, and the decrease was very slight. During treatment the serum of this animal exhibited pneumococcidal-promoting power greater than it had possessed before infection.

To test the effectiveness of sulfapyridine in the presence of more massive pneumococcemia, 4 additional bacteremic dogs were selected for treatment, all but 1 having a colony count of more than 1,000 per cc. of blood. Each was given a total of 5.7 or 6 grams of the drug. Its administration was begun with a large dose ( 2 or 3 grams) 30 to 72 hours after infection, and continued with 1 gram a day in divided doses until death or apparent recovery from infection occurred. All died ultimately.

One animal (Table IV, $284 \mathrm{~T}$ ) in the 30th hour of the disease, the time at which treatment was instituted, had a bacteremia of 10,000 colonies per cc. of blood, and its serum had no demonstrable pneumococcidal-promoting action. Blood drawn 18 hours later (on the 3rd day of the disease) was sterile on culture, and the serum exhibited in a serum-leukocyte mixture pneumococcidal action against 1,000 pneumococci. A serum sample obtained on the 4th day when the blood contained $4 \mathrm{mgm}$. per cent of sulfapyridine showed pneumococcidal-promoting properties to an even greater degree, but did not prevent the growth of an inoculum of 10 organisms after the serum had been subjected to a temperature of $56^{\circ} \mathrm{C}$. for one-half hour. Moreover, the sample contained no demonstrable mouse-protective antibodies characteristic of acquired immunity. Death occurred on the 5th day. At autopsy the pericardial sac was found distended with about $50 \mathrm{cc}$. of thick purulent exudate which on microscopic examination contained innumerable diplococci. When the Neufeld test was applied to 
TABLE IV

Course of disease in 2 of 4 bacteremic dogs in which treatment was begun later than 24 hours after infection

\begin{tabular}{|c|c|c|c|c|c|c|c|c|c|c|c|c|c|c|}
\hline \multirow{3}{*}{ Day of disease } & \multicolumn{7}{|c|}{ Dog No. $284 T$} & \multicolumn{7}{|c|}{ Dog No. $288 T$} \\
\hline & \multirow{2}{*}{$\begin{array}{c}\text { Before } \\
\text { infec- } \\
\text { tion }\end{array}$} & \multicolumn{3}{|c|}{ 2nd } & \multirow{2}{*}{ 3rd } & \multirow{2}{*}{ 4th } & \multirow{2}{*}{5 th } & \multirow{2}{*}{$\begin{array}{c}\text { Before } \\
\text { infec- } \\
\text { tion }\end{array}$} & \multirow{2}{*}{ 2nd } & \multirow{2}{*}{ 3rd } & \multirow{2}{*}{ 4th } & \multirow{2}{*}{5 th } & \multirow{2}{*}{ 6th } & \multirow{2}{*}{ 7th } \\
\hline & & $\begin{array}{l}\text { 24th } \\
\text { hour }\end{array}$ & $\begin{array}{l}\text { 30th } \\
\text { hour }\end{array}$ & $\begin{array}{l}\text { 36th } \\
\text { hour }\end{array}$ & & & & & & & & & & \\
\hline Dosage of sulfapyridine, grams... & & & 2 & 1 & 1 & 1 & 1 & & & & 2.7 & 1 & 1 & $1^{*}$ \\
\hline $\begin{array}{l}\text { Blood culture, colonies pneumo- } \\
\text { cocci per cc. of blood.......... }\end{array}$ & & 2,000 & 10,000 & 1,500 & 0 & 11 & 1 & & 9 & 1,800 & 1,100 & 2 & 1 & $0 \ddagger$ \\
\hline $\begin{array}{l}\text { Pneumococcidal-promoting power } \\
\text { of serum, number of pneumo- } \\
\text { cocci killed in serum-leukocyte } \\
\text { mixture...................... }\end{array}$ & & & 0 & & $10^{3}$ & $10^{6}+$ & & $10^{4}$ & & 0 & & & $10^{5}$ & \\
\hline $\begin{array}{l}\text { Concentration of sulfapyridine in } \\
\text { blood, mgm. per cent ......... }\end{array}$ & & & & 4.7 & 10.4 & 4.0 & 2.1 & & & & & 10.0 & 4.0 & \\
\hline White blood count, thousands... & 6.5 & 1.6 & 1.8 & 1.8 & 2.2 & 4.8 & 8.2 & 9.6 & 3.3 & 4 & 8 & 16 & 12 & 24 \\
\hline $\begin{array}{l}\text { Extent of pulmonary involve- } \\
\text { ment (x-ray) } \ldots \ldots \ldots \ldots \ldots \ldots \ldots\end{array}$ & & & $\begin{array}{l}\text { LLL } \\
\text { LML }\end{array}$ & & & & & & & & $\begin{array}{l}\text { LLL } \\
\text { RUL }\end{array}$ & & & \\
\hline
\end{tabular}

them, all the visible organisms showed a typical capsular swelling. The exudate contained 5 $\mathrm{mgm}$. per cent of sulfapyridine. No pneumococci could be cultured from the lungs or heart's blood.

An x-ray of the chest taken on the 2nd day of the disease, a few hours before treatment was begun, showed a cardiac shadow not unusual in size and shape. On the 3rd day the silhouette was slightly larger than before, and on the 5th day, it was globular and much enlarged. The red blood count on the 5th day was 6,100,000.

Another animal (not shown in the table) pursued a similar course. Treatment was begun on the 5th day when the blood on culture contained 6,000 colonies per cc. and the serum no longer possessed pneumococcidal-promoting action. By the 7th day the colony count had fallen to 50 , but on the 8th day, the day of death, it rose to 10,000 . Empyema was found at autopsy. The exudate contained Type I pneumococci and a concentration of sulfapyridine of $0.9 \mathrm{mgm}$. per cent. It was not possible to ascertain when the empyema had begun. However, there was a suggestive shadow already present on the day treatment was started. The red blood count on the 5th day was 5,300,000.
Among the 16 control dogs that died, 6 of the 7 that had lived for more than 72 hours were found at autopsy to have empyema. This complication did not occur in those dying earlier in the disease. Purulent pericarditis was not observed in the control dogs.

In the other 2 members of the group of 4 bacteremic dogs specially selected for treatment, severe anemia and jaundice developed. In each case the blood became sterile several days before death, and autopsy cultures from lungs and heart's blood yielded no pneumococci. One of the dogs (Table IV, $288 \mathrm{~T}$ ) was treated on the 4th day of the disease when its blood on culture contained 1,100 colonies per cc. The pneumococcidal-promoting power of the serum had already disappeared. By the 6th day the colony count had dropped to one, and anti-pneumococcal action of the serum had returned. Blood collected on the 9th day contained antibodies characteristic of acquired immunity; the 6th day's sample was not tested for heat-stable immune bodies. The temperature had become normal on the 5th day and the dog seemed to be recovering. The last dose of drug was given on the 8th day. Death occurred 3 days later. At autopsy the skin 
and mucous membranes were deeply icteric. Unclotted blood from the heart contained 1,100,000 red cells per cubic millimeter, and they showed striking variation in size, shape, and staining qualities.

The fourth dog was first treated on the 4th day of the disease, when there was a bacteremia of 78 colonies per cc. of blood. The serum had retained some pneumococcidal-promoting activity, but possessed much less than it did before infection. The blood became sterile on the 5th day. The serum on that day had no mouse-protective action. The temperature became normal on the 5th day; treatment was discontinued on the 6th day. The red blood count on the 7 th day was $3,400,000$. The dog died on the 8 th day, presenting the same findings as the preceding animal.

\section{Production of lobar pneumonia in dogs receiving sulfapyridine prior to infection}

In 6 dogs (Table V) a fully developed lobar pneumonia evolved in 24 hours despite the administration of large doses of sulfapyridine before and after inoculation, and despite its presence in the blood in concentrations equal to or greater than those obtaining in experiments where the drug was regularly curative.

The dogs were sacrificed 24 hours after infection. Four were definitely ill at that time, having temperatures of $103^{\circ}$ or more. None were leukopenic or bacteremic, however. At autopsy there was, with one exception, consolidation of at least the greater part of the lobe which received the infecting inoculum, and in 3 instances there were small lesions in other lobes as well. In the exudate from 4 of the primary lesions numerous pneumococci were readily seen. They showed no alteration in morphology or staining qualities as observed by the Gram stain. When the exudate was mixed with Type I antipneumococcic rabbit serum the organism showed immediately a positive "quellung" reaction. There appeared to be no alteration of the capsules. Cultures from these lesions and from one other contained typespecific pneumococci.

\section{DISCUSSION}

The potential efficacy of sulfapyridine as a lifesaving therapeutic agent in pneumococcic infec-
TABLE V

Production of lobar preumonia in dogs receiving sulfapyridine prior to infection

Dogs sacrificed 24 hours after infection

\begin{tabular}{|c|c|c|c|c|c|c|c|c|}
\hline \multirow{3}{*}{$\begin{array}{l}\text { Dog } \\
\text { num- } \\
\text { bex }\end{array}$} & \multirow{3}{*}{$\begin{array}{c}\text { Infect- } \\
\text { ing } \\
\text { doge } \\
\text { of } \\
\text { cul- } \\
\text { ture }\end{array}$} & \multirow{2}{*}{\multicolumn{2}{|c|}{$\begin{array}{l}\text { Concentra- } \\
\text { tion of drug } \\
\text { in the blood }\end{array}$}} & \multirow{3}{*}{$\begin{array}{c}\text { Extent } \\
\text { of } \\
\text { lung } \\
\text { involve- } \\
\text { ment } \\
\text { at } \\
\text { au- } \\
\text { topsy }\end{array}$} & \multicolumn{3}{|c|}{ Lung puncture at autopey } & \multirow{3}{*}{$\begin{array}{l}\text { Reotal } \\
\text { temper- } \\
\text { ature } \\
\text { when } \\
\text { sacri- } \\
\text { ficed }\end{array}$} \\
\hline & & & & & \multirow[b]{2}{*}{ Culture } & \multicolumn{2}{|c|}{$\begin{array}{c}\text { Direct } \\
\text { examination }\end{array}$} & \\
\hline & & $\begin{array}{l}\text { When } \\
\text { in- } \\
\text { fected }\end{array}$ & $\begin{array}{l}\text { When } \\
\text { sacri- } \\
\text { ficed }\end{array}$ & & & $\begin{array}{l}\text { Gram- } \\
\text { posi- } \\
\text { tive } \\
\text { diplo- } \\
\text { cocoi }\end{array}$ & $\begin{array}{l}\text { Neu- } \\
\text { feld } \\
\text { reac- } \\
\text { tion }\end{array}$ & \\
\hline $\begin{array}{l}251 \mathrm{~T} \\
281 \mathrm{~T} \\
271 \mathrm{~T} \\
272 \mathrm{~T} \\
273 \mathrm{~T} \\
280 \mathrm{~T}\end{array}$ & $\begin{array}{l}c . \\
1.0 \\
1.0 \\
0.02 \\
0.02 \\
0.02 \\
0.02\end{array}$ & $\begin{array}{r}\text { mom. } \\
\text { per } \\
\text { cent } \\
10.0 \\
4.9 \\
3.3 \\
18.0 \\
12.0 \\
12.8\end{array}$ & $\begin{array}{c}\text { mom. } \\
\text { per } \\
\text { cent } \\
2.8 \\
3.7 \\
3.6 \\
2.8 \\
5.1 \\
5.0\end{array}$ & $\begin{array}{c}1 \\
1 \\
1 / 3 \\
1 \\
<1 \\
>1\end{array}$ & $\begin{array}{c}\text { Pneumococcus } \\
\text { Pneumococcus } \\
\text { Pneumococcus } \\
0 \\
\text { Pneumococous } \\
\text { Pneumococcus }\end{array}$ & $\begin{array}{l}+ \\
+ \\
0 \\
0 \\
+ \\
+\end{array}$ & 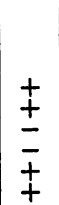 & $\begin{array}{c}\text { degress } \\
\text { Pahren- } \\
\text { heit } \\
104.0 \\
104.0 \\
103.8 \\
102.5 \\
104.3 \\
102.4\end{array}$ \\
\hline
\end{tabular}

* Suspended in 1 cc. of starch-broth medium. $>=$ More than.

$<=$ Less than.

Total quantity of drug before infection: $271 \mathrm{~T}, 272 \mathrm{~T}$ $=3$ grams; $273 \mathrm{~T}, 280 \mathrm{~T}, 281 \mathrm{~T}=4$ grams; $251 \mathrm{~T}=5$ grams; given in 2 divided doses, the first dose 18 to 24 hours before infection, the second 6 to 12 hours before infection.

Total quantity of drug after infection: $271 \mathrm{~T}, 272 \mathrm{~T}$, $251 \mathrm{~T}=2$ grams; $273 \mathrm{~T}, 280 \mathrm{~T}, 281 \mathrm{~T}=4$ grams; given in 2 divided doses, the first dose 6 hours after infection, the second 12 to 18 hours after infection.

tion is especially evident in the recovery of certain of the dogs showing a well advanced disease by the end of 18 to 24 hours, when treatment was begun. In several of these instances the findings were such as to indicate a high probability of fatal termination. That it is able to promote an arrest of infection is also shown by the brevity of the febrile stage, the restricted size of the pulmonary lesions, and the limited occurrence of bacteremia in dogs treated earlier in the disease. A pronounced antipneumococcic effect of the drug is obvious even in those instances where treatment was instituted at a time when the blood contained thousands of pneumococci per cc., though focal suppurative complications with toxemia of severe infection and drug intoxication prevented ultimate recovery.

A single strain of pneumococcus Type I was employed in these experiments. Because there is evidence that the several types of pneumococci $(1,15)$, and also strains of the same type $(6)$, vary in their susceptibility to sulfapyridine, broad conclusions concerning its efficacy in the treatment of canine pneumonia are not permissible at this time. However, the results of the present study, 
obtained in a highly fatal lobar pneumonia in an animal with antipneumococcic resistance comparable to that of man, are in complete accord with clinical observations (16) and indicate that the drug possesses remarkable curative properties.

The ability of sulfapyridine to re-enforce the body's natural antipneumococcic defense is reflected in the augmented pneumococcidal-promoting power of serum collected during the course of treatment, as tested in serum-leukocyte mixtures. This increased action may be attributable to an inhibition of the bacterial growth which occurs before completion of phagocytosis. An alternate explanation is that the drug renders pneumococci more susceptible to phagocytosis, perhaps by causing alteration of the capsules.

Whitby (1) has described changes in the capsule of pneumococci obtained from the peritoneal exudate of mice treated with sulfapyridine, and has stated that after 4 hours, in large numbers of cocci, no capsules could be found by staining methods. He has pointed out that this capsular degeneration was an in vivo phenomenon, and that it may have been a secondary effect, representing a process whereby the body rids itself of dead pneumococci. Telling and Oliver (17) found that after patients had been treated with sulfapyridine the organisms isolated from sputum had lost capsules and type-specificity and that these were restored by repeated mouse passage. Hilles and Schmidt (18), and Greey, MacLaren, and Lucas (19) have reported isolation of nonencapsulated pneumococci from the blood of sulfapyridine-treated mice. Long (20) and Reid (21) have been unable to find specific capsular changes in the peritoneal exudates of mice. Fleming (5b) observed no changes in the capsules of pneumococci grown in vitro in the blood of patients in the presence of sulfapyridine.

We found normal capsular swelling regularly when the Neufeld test was applied to pneumococci growing in blood cultures made during the course of treatment, and to those obtained directly from the lungs of dogs that received the drug before and after infection and were sacrificed 24 hours afterwards. If loss of capsule had occurred, it is unlikely that non-encapsulated pneumococci could have existed except momentarily in the presence of actively phagocyting leukocytes. Thus, while our observations do not exclude the possibility that sulfapyridine produces capsular changes, they provide no evidence for such an effect.

To account for the drug's curative action in canine pneumonia, no more than a bacteriostatic effect need be assumed, for if not overwhelmed by rapid pneumococcus growth, the immediate defense mechanism of the body (22) is able to retard the progress of infection until the normal recovery processes (including the macrophage reaction in the lung (23)) can mobilize. That the natural antipneumococcic defense, at least the humoral component, can again manifest activity even after having been markedly depressed (24), is indicated by the reappearance of heat-labile opsonins in the sera of dogs $284 \mathrm{~T}$ and $288 \mathrm{~T}$ as bacteremia diminished with treatment.

It follows, then, that any noteworthy reduction in rate of pneumococcus growth and the resultant slowing of outward flow of pneumococcus-laden edema fluid from the lesion would retard spread of infection, inasmuch as polymorphonuclear leukocytes at the spreading border are actively phagocytic, at least early in the course of the disease (22). That such a result is not immediate is clearly evident in those experiments in which administration of the drug prior to infection failed to prevent the development of the experimental lesion. In untreated dogs the smaller infecting dose employed $(0.02 \mathrm{cc}$. of culture in $1 \mathrm{cc}$. of starch broth paste) has been found by Robertson and Fox (11) to produce a lesion which on the average occupies eventually but one-quarter of the lung field by $x$-ray (approximately 1 and one-half lobes), and results in a mortality of only 8 per cent.

This evidence of the delayed action of sulfapyridine is comparable to the findings of McIntosh and Whitby (25) in experiments on mice and on citrated rabbit's blood.

That the normal defensive elements play an essential part in bringing about recovery in treated dogs is indicated by the persistence of purulent complications in dogs $275 \mathrm{~T}$ and $284 \mathrm{~T}$. The findings in the latter dog are especially significant, for while the blood and lungs became free of pneumococci as determined at autopsy, the pericardial exudate contained myriads of pneumococci despite the presence of sulfapyridine in concentration of $5 \mathrm{mgm}$. per cent. It is known that 
leukocytes in such exudates lose activity after a day or so.

Mouse-protective antibodies, characteristic of acquired immunity, were found in dogs recovering with treatment in about the same frequency and titer as ordinarily found in dogs recovering spontaneously. None were found before the 3rd day after recovery in 4 dogs tested. Thus, here as well as in spontaneous recovery $(8,26)$, the rôle of these substances cannot be evaluated.

Whether or not drug intoxication was responsible for the profound anemia observed in 2 dogs cannot be determined. Powell and Chen (27) have given normal dogs as much as 1 gram of sulfapyridine per kilo of body weight for as long as 4 weeks without finding any significant reduction in red blood count. In this laboratory severe anemia and jaundice have been observed otherwise but once in over a thousand dogs with experimental pneumonia, and that was in an actively immunized animal that had recovered from a 5 days' illness. However, many dogs have recovered spontaneously from prolonged and severe infections without developing the disorder. The fact that in the present series the anemia occurred only in dogs with severe infection suggests a dual etiology, namely, drug intoxications and toxemia of infection.

\section{SUMMARY}

1. In the dog, a species with natural antipneumococcic resistance comparable to that of the human being, sulfapyridine exerted a marked curative effect in a highly fatal Type I pneumococcic pneumonia.

2. The pulmonary lesion seldom spread after the 24th hour of treatment but it was not immediately arrested. Administration of sulfapyridine before infection did not prevent the evolution of a fully developed lobar pneumonia.

3. Most of the animals had fever for at least 24 hours after the beginning of treatment.

4. Treatment inhibited blood-stream invasion. Bacteremia already established disappeared within 24 hours or the colony count fell sharply.

5. Influence of the drug was evident even in far advanced stages of the disease but its effectiveness was limited in the presence of suppurative complications.
6. During treatment the serum exhibited increased pneumococcidal-promoting action in serum-leukocyte mixtures or regained that property when it had disappeared.

7. Pneumococci obtained from lungs, blood, and pyemic exudate showed no alteration of the capsules.

8. Treatment was followed by hemolytic anemia in 2 instances.

9. The mechanism of the drug's therapeutic action is discussed.

We wish to acknowledge the helpful advice given us during this study by Dr. O. H. Robertson.

\section{BIBLIOGRAPHY}

1. Whitby, L. E. H., Chemotherapy of pneumococcal and other infections with 2 ( $p$-aminobenzenesulphonamido) pyridine. Lancet, 1938, 1, 1210.

2. Schmidt, L. H., and Hilles, C., Sulfapyridine: Immunity to reinfection with Type I pneumococcus. Proc. Soc. Exp. Biol. and Med., 1939, 41, 111.

3. MacLeod, C. M., Unpublished data presented at A. M. A. pneumonia symposium, St. Louis, 1939.

4. a. Powell, H. M., and Jamieson, W. A., Combined therapy of pneumococcic rat infections with rabbit antipneumococcic serum and sulfapyridine. J. Immunol., 1939, 36, 459.

b. Powell, H. M., and Jamieson, W. A., Combined immuno and chemotherapy of pneumococcus rat infections. Proc. Soc. Exp. Biol. and Med., 1939, 41, 281.

5. a. Fleming, A., The antibacterial action in vitro of 2 (p-aminobenzenesulphonamido) pyridine on pneumococci and streptococci. Lancet, 1938, $2,74$.

b. Fleming, A., The antibacterial power of the blood of patients receiving 2 ( $p$-aminobenzenesulphonamido) pyridine. Lancet, 1938, 2, 564.

6. MacLean, I. H., Rogers, K. B., and Fleming, A., M. and B. 693 and pneumococci. Lancet, 1939, 1, 562.

7. Kepl, M., and Gunn, F. D., Sulfapyridine and serum therapy in experimental lobar pneumonia of rats. Proc. Soc. Exp. Biol. and Med., 1939, 40, 529.

8. Robertson, O. H., and Cornwell, M. A., Study of resistance of normal human beings to recently isolated strains of pathogenic pneumococci. J. Exper. Med., 1930, 52, 267.

9. Robertson, . O. H., Recent studies on experimental lobar pneumonia; pathogenesis, recovery and immunity. J. A. M. A., 1938, 111, 1432.

10. Terrell, E. E., Robertson, O. H., and Coggeshall, L. T., Experimental pneumococcus lobar pneumonia in the dog. I. Method of production and course of disease. J. Clin. Invest., 1933, 12, 393.

11. Robertson, O. H., and Fox, J. P., Relationship of infecting dosage, leucocytic response, bacteremia, 
and extent of pulmonary involvement to outcome of experimental lobar pneumonia in dog. J. Exper. Med., 1939, 69, 229.

12. Marshall, E. K., Jr., and Litchfield, J. T., Jr., The determination of sulfanilamide. Science, 1938, 88, 85.

13. Robertson, O. H, and Sia, R. H. P., Studies of growth inhibition. II. A method for demonstrating the growth-inhibiting and bactericidal action of normal serum-leucocyte mixtures. J. Exper. Med., 1924, 39, 219.

14. Wu, Ching, Visceral displacement in pneumonia; roentgenologic and experimental study. Radiology, 1932, 19, 215.

15. Schmidt, L. H., and Hilles, C., Further studies on therapeutic properties of sulfapyridine in experimental pneumococcus infections. Proc. Soc. Exp. Biol. and Med., 1939, 40, 611.

16. a. Evans, G. M., and Gaisford, W. F., Treatment of pneumonia with 2(p-aminobenzenesulphonamido) pyridine. Lancet, 1938, 2, 14.

b. Flippin, H. F., Lockwood, J. S., Pepper, D. S., and Schwartz, L., Treatment of pneumococcic pneumonia with sulfapyridine; progress report on observations in 100 cases. J. A. M. A., 1939, 112, 529.

c. Graham, D., Warner, W. P., Dauphinee, J. A., and Dickson, R. C., The treatment of pneumococcal pneumonia with Dagenan (M. and B. 693). Canad. M. A. J., 1939, 40, 325.

d. Meakins, J. C., and Hanson, F. R., The treatment of pneumococcic pneumonia with sulfapyridine. Canad. M. A. J., 1939, 40, 333.

e. Pepper, D. S., Flippin, H. F., Schwartz, L., and Lockwood, J. S., The results of sulfapyridine therapy in 400 cases of typed pneumococcic pneumonia. Amer. J. M. Sc., 1939, 198, 22.

17. Telling, M., and Oliver, W. A., Case of massive pneumonia, Type III with massive collapse, treated with 2 (p-aminobenzenesulphonamido) pyridine. Lancet, 1938, 1, 1391.

18. Hilles, C., and Schmidt, L. H., Sulfanilamidopyridine (2-para-aminobenzenesulfonamidopyridine) in experimental infections with type XXII pneumococcus. Proc. Soc. Exper. Biol. and Med., 1939, 40, 73.

19. Greey, P. H., MacLaren, D. B., and Lucas, C. C., Comparative chemotherapy in experimental pneumococcal infections. Canad. M. A. J., 1939, 40, 319.

20. Long, P. H., Sulfapyridine. J. A. M. A., 1939, 112, 538.

21. Reid, R. D., Observations on the mode of action of sulfapyridine on pneumococcus. Proc. Soc. Exp. Biol. and Med., 1939, 41, 437.

22. Robertson, O. H., Coggeshall, L. T., and Terrell, E. E., Experimental pneumococcus lobar pneumonia in the dog. III. Pathogenesis. J. Clin. Invest., 1933, 12, 467.

23. a. Robertson, O. H., Coggeshall, L. T., and Terrell, E. E., Experimental pneumococcus lobar pneumonia in the dog. II. Pathology. J. Clin. Invest., 1933, 12, 433.

b. Robertson, O. H., and Coggeshall, L. T., Local recovery in experimental pneumococcus lobar pneumonia in the dog. J. Exper. Med., 1938, 67, 597.

24. Robertson, O. H., Hamburger, M., and Gregg, L. A., Unpublished data.

25. McIntosh, J., and Whitby, L. E. H., Mode of action of drugs of sulphonamide group. Lancet, 1939, 1, 431.

26. Terrell, E. E., Changes in humoral immunity occurring during the early stages of experimental pneumococcus infection. J. Exper. Med., 1930, 51, 425.

27. Powell, H. M., and Chen, K. K., The action of sulfapyridine (2-sulfanilylamidopyridine). J. Pharmacol. and Exper. Therap., 1939, 67, 79. 